\section{A produção de conhecimento no Serviço Social. 0 mundo do trabalho em debate}

\section{The production of knowledge in Social Sciences. The world of work in debate}

Autor: Ricardo Lara

São Paulo, Editora Unesp, 2011, 322 p.

\section{Claudia Mazzei Nogueira*}

O Serviço Social (e as áreas das Ciências Sociais e Humanas em geral) recebeu uma nova contribuição para a reflexão da produção do conhecimento. Trata-se do livro de Ricardo Lara - A produção de conhecimento no Serviço Social. O mundo do trabalho em debate - , que não tem só o papel de explicitar a importância da categoria trabalho para a produção do conhecimento, mas também o objetivo

\footnotetext{
* Professora do departamento de Saúde, Educação e Sociedade no curso de Serviço Social da Universidade Federal de São Paulo — campi Baixada Santista Unifesp, Santos/SP, Brasil. E-mail: mazzeinogueira@ uol.com.br.
}

de contribuir com o debate e a reflexão sobre o mundo do labor, reflexão esta extremamente importante para a intervenção profissional, pois o ato da reflexão diferencia a práxis social da prática profissional.

Nas palavras do próprio autor: "A produção de conhecimento no Serviço Social sobre o mundo do trabalho [...] assenta-se no debate oriundo das polêmicas em torno do trabalho que se intensificaram nas Ciências Sociais e Humanas no final da década de 1970". E complementa, "O Serviço Social, [...] em uma forma de encarar a pesquisa e a produção do conhecimento em uma perspectiva contra-hegemônica, posicionou-se criticamente" contra o racionalismo instrumental. "Os assistentes sociais não sucumbiram às teses do 'fim da história', 'fim do trabalho', mas buscaram, ensejados pelos seus órgãos representativos [...], fortalecer o debate em torno das principais questões que envolvem as determinações sociais fundamentando-se nos marcos da teoria social crítica" (p. 283, 286).

Neste sentido, Lara elege como teoria fundante para as suas análises as desenvolvidas por Marx e György Lukács, centralmente no que diz respeito à categoria trabalho como fundante do ser social. Sendo fiel a suas influências marxianas e lukacsianas, ele discorrerá sobre a produção do conhecimento no Serviço Social, apresentando no primeiro capítulo o trabalho como tema relevante nas pesquisas dos diversos programas de pós-graduação dessa área. Contempla ainda a emergência dos assistentes sociais também como pesquisadores. 
No segundo capítulo, o autor faz análises frente ao que foi produzido e publicado entre 1996 a 2006, pelos(as) pesquisadores(as) do Serviço Social sobre o mundo do trabalho, indicando os diversos eixos ligados a esse tema e presentes na produção da profissão, incluídas as revistas ou periódicos correspondentes.

Em seu terceiro e último capítulo, aliás, o mais denso deles, Ricardo Lara apresenta, entre outros pontos, uma crítica contundente à condução teórica no modelo de "universidade produtivista". Diz o autor: "São poucas as instituições de ensino superior que apresentam projetos acadêmicos de resistência e força política contra a lógica mercadológica imposta ao ensino superior". E continua: “[...] desde os programas de pós-graduação, passando pelas agências de fomento à pesquisa, os horizontes estão cravados de acordo com os ditames da produção quantitativa do conhecimento, que é a radicalização da ciência burguesa produtivista".

Nessa direção, ele apresenta também uma defesa significativa dos cursos e, indiretamente, dos programas de pós-graduação em Serviço Social, que, por meio de suas diretrizes curriculares, não foram formuladas desconsiderando o mundo real, mas, ao contrário, suas diretrizes foram e são construídas e inseridas no âmbito das relações de produção e reprodução da vida social, uma vez que essa profissão é eminentemente interventiva e necessita, como condição vital para a sua práxis, do conhecimento da realidade social.
Por essa razão é que o autor afirma que os "objetos de pesquisa" do Serviço Social partem da realidade concreta, determinada por relações sociais que produzem e reproduzem a vida material, inseridas nas complexas mediações entre o capital e o trabalho, diferenciando-se de muitas das produções de conhecimento dos pesquisadores(as) das demais ciências sociais. Por isso, Lara lembra que Lukács, ao afirmar a existência da "decadência ideológica”, está indicando que os ideólogos representantes da ciência burguesa produzem conhecimento partindo da premissa de fuga da realidade. Também nesse capítulo o autor se aproxima ainda mais dos pertinentes pressupostos da perspectiva ontológica materialista dialética, percorrendo os nexos causais entre a categoria trabalho e a ciência genuinamente humana.

Em suas considerações finais, mantendo-se coerente com sua matriz teórica, Lara retorna ao seu ponto de partida, agora rico em múltiplas determinações, realizando, em suas palavras, "uma interlocução" com os mais significativos autores que, de certa forma, influenciaram e continuam influenciando a produção de conhecimento do Serviço Social.

Desse modo, segundo o próprio autor, a pesquisa realizada em seu doutoramento e agora publicada em forma de livro, "foi de cunho bibliográfico", buscando as bases teóricas que se vinculassem com a perspectiva da "descrição ontológica do ser social sobre bases materialistas", conforme a formulação de Lukács em seu capítulo "Os princípios ontológicos fundamentais 
de Marx", presente em A ontologia do ser social.

Ainda como nos indicou Ricardo Lara, essa produção tem como objetivo central construir um conhecimento que propicie o fortalecimento "na compreensão das contradições da vida social, que é orquestrada de forma destrutiva pelo sistema do capital". Em síntese, esse livro traz em seu conteúdo um claro posicionamento da importância da categoria trabalho e sua centralidade, tanto na produção do conhecimento, quanto na intervenção profissional do Serviço Social, perquirindo explicitamente uma opção ideológica e política em favor do trabalho, da classe trabalhadora e, consequentemente, do ser social.

Desta forma, esse belo livro se torna leitura indispensável para todos e todas, sejam assistentes sociais ou não, que refletem sobre a temática do mundo do trabalho e da produção do conhecimento, que se pautam, para as suas análises, na teoria social crítica.

Recebido em 26/10/2012

Aprovado em 10/12/2012 